\title{
4-Stroke CI Engine: An Experimental Comparison of Performance Characteristics for $14 \%$ Biodiesel \& Pure Diesel
}

\author{
Hafiz Muhammad Bilal Ameer ${ }^{1 \star}$, Muhammad Faizan Ameer ${ }^{2,3}$
}

\begin{abstract}
${ }^{1}$ Department of Mechanical Engineering, University of Engineering \& Technology, Lahore, PAKISTAN
${ }^{2}$ Department of Technology, The University of Lahore, Raiwand Road, Lahore, PAKISTAN

${ }^{3}$ Department of Industrial and Manufacturing Engineering, University of Engineering and Technology, Lahore, PAKISTAN

*Corresponding Author: bilalameer2007@gmail.com
\end{abstract}

Citation: Ameer, H. M. B. and Ameer, M. F. (2020). 4-Stroke Cl Engine: An Experimental Comparison of Performance Characteristics for 14\% Biodiesel \& Pure Diesel. European Journal of Sustainable Development Research, 4(4), em0142. https://doi.org/10.29333/ejosdr/8568

ARTICLE INFO

Received: 18 Jan. 2020

Accepted: 13 Aug. 2020

\begin{abstract}
Global oil reserves are facing great stress because of massive fuel consumption worldwide and the booming world population. These fossil fuels, when processed, affect the environment by releasing greenhouse gases. The outstanding usage of oil inspired many countries to develop alternative fuels. Biodiesel is the future prospect to fulfil the energy needs. It is compatible, ready to use fuel and can easily be deployed in the existing engines by combining it with conventional fuel (diesel). Biodiesel emits a lower amount of greenhouse gases. In this experiment, we first synthesized biodiesel using methanol, $\mathrm{NaOH}$ and vegetable oil through transestrification process. After that, we prepared a sample for $14 \%$ biodiesel which was then used to run a 4 -stroke compression ignition $(\mathrm{Cl})$ engine that was attached to the engine testbed. After that, we re-run the same 4-stroke $\mathrm{Cl}$ Engine with pure-diesel. From the data obtained and subsequent data-analysis, the $14 \%$ biodiesel came out to be less efficient (avg. 3\% lower brake power and 8.9\% lower brake thermal efficiency) and more expensive (avg. 12.8\% higher fuel consumption) as compared to pure-diesel.
\end{abstract}

Keywords: biodiesel, sustainability, engines, environment, energy, fuel, diesel, power

\section{INTRODUCTION}

Today, the global population is increasing at a rapid pace and the countries around the world are consuming a massive amount of fossil fuels each day in order to meet the needs of the growing population and industry. Fossil fuels are the primary source from which the world's energy requirement is achieved (Yoon et al., 2019). Further, It is estimated that the world's energy requirement is going to increase by $41 \%$ in 2030 as compared to 2012 (Teoh et al., 2019). As far as the transportation sector is concerned, the world has already witnessed a massive rise in use of vehicles over the years. Due to this, the transportation sector alone is consuming $29 \%$ of the world's total energy (Kim et al., 2018). Energy consumption is found to increase by $2 \%$ per year due to the transportation sector (Songstad et al., 2011). On one side, such a large scale use of fossil fuels (oil, gas, coal etc.) is causing depletion and shortness of energy rsources for our future generations while on the other hand, the fossil fuels themselves are creating environmental issues such as global warming and climate change (Ge et al. 2015; Kim et al., 2018; Liu et al., 2018; Niculescu et al., 2019). The exhaust from Cl and SI engines has led to $80 \%$ increased greenhouse gas emissions as by 2002 (Dufey, 2006). The combustion in $\mathrm{SI}$ and $\mathrm{Cl}$ engines emits carbon dioxide $\left(\mathrm{CO}_{2}\right)$, oxides of nitrogen and carbon-monoxide that are posing serious problems to our environment and health. As a result, the world is shifting towards renewable energy sources as they are considered an environment-friendly replacement for fossil fuel. These renewable energy sources would eventually reduce the massive consumption of fossil fuels as the global trend slowly shifts towards renewable energy sources (Jaichandar and Annamalai, 2011).

When vegetable oil is treated with ethanol with some combination of catalyst, mono-alkyl esters are produced. Without the use of catalyst, the reaction would be quite slow and unachievable. The temperature must be $60^{\circ} \mathrm{C}$ or $70^{\circ} \mathrm{C}(\mathrm{Singh}$ et al., 2014). Glycerin is also produced as a by-product, which can be removed. Soya bean, coconut, canola, jatropha are some of the plants which are used in its synthesis. Animal fat and used oil can also be used. It can also be manufactured from algae (Meher, Sagar, and Naik, 2006). From 1978, the US Department of Energy's Office of Fuels Development funded a program to manufacture renewable transportation fuel from algae. Wood and straw after gasification stage can also be converted into biodiesel. Biodiesel can be used in its pure form in adaptive vehicles and can be blended with conventional diesel. In the 1940s, Tung oil and different vegetable oils were used to produce different proportions of diesel and kerosene. The interest was also shown in the USA to convert cottonseed oil into fuel in the same era (Ma and Hanna, 1999). In the late 1970s and 1980s, when oil prices rose 


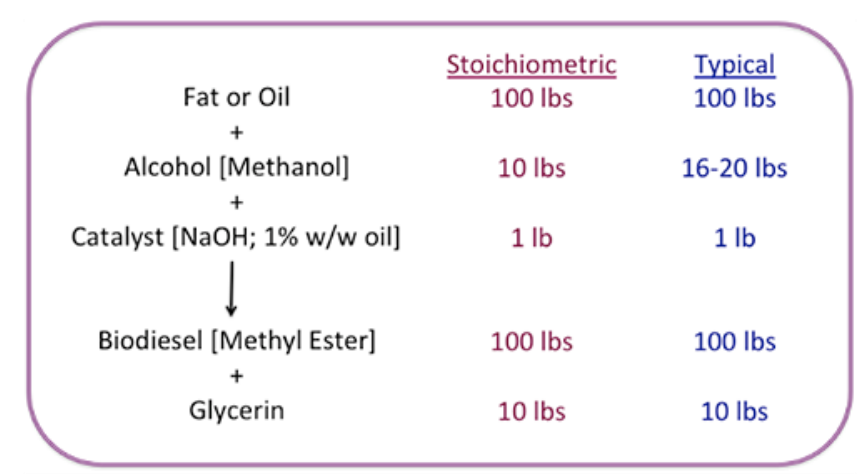

Figure 1. Stoichiometric and typical amounts of reactants and products

outstandingly, inspired many to research in alternative fuels. The use of vegetable oil instead of petroleum was proposed in the early 1980s in the US. European Union (EU) is a key producer of biodiesel. EU capacity of biodiesel production is increasing annually by 81 per cent. Approximately 76 million litres were produced in the US in 2004 from soya. As soya-bean is a valuable crop in the US, the target price as calculated by USDA is $21.2 \mathrm{c} / \mathrm{kg}$ (Knothe, 2005). According to a study conducted in 2005, $90 \%$ of the time biofuel is used in residential fuel consumption in rural areas of South-Asian countries. In urban areas there has been seen a gradual increase in consumption of biofuels instead of diesel.

The goal, therefore, is to find a biofuel which could be a suitable replacement for fossil fuels (Fan and Burton, 2009). One such biofuel, that is used in this study, is biodiesel. Biodiesel is an environment-friendly fuel that can be produced by either esterification or transesterification (Sheehan et al., 1998). It can be used with pure diesel in a concentration of up to $20 \%$ and has a calorific value very much comparable to that of pure diesel (Van Gerpen, 2005). Due to its comparable calorific value and compatibility to that of pure diesel, it can be used as an alternative fuel in $\mathrm{Cl}$ and $\mathrm{SI}$ engines if certain modifications are done in these respective engines. It is now an established fact that the biodiesel reduces all exhaust emissions except nitrogen oxides (which are increased) thereby reducing the dangerous effects on environment and health (Abed et al., 2019). In our study, we have used a sample of $14 \%$ biodiesel blend ( $14 \%$ biodiesel $+86 \%$ pure diesel) to study the performance characteristics of the $\mathrm{Cl}$ engine without any engine modifications. The reason why we used $14 \%$ biodiesel is that it is a moderate blend (as compared to high concentration of $20 \%$ biodiesel or lower concentration of $5 \%$ ) which will reduce the engine emissions moderately and, at the same time, wouldn't much affect the engine brake power. The focus of our study is the performance characteristics; therefore, combustion characteristics or exhaust emissions have not been discussed.

\section{MATERIALS AND METHODS}

\section{Chemicals and Apparatus Required for synthesis of Biodiesel}

- Methanol Oxide

- Vegetable oil

- Alcohol

- Flask

- Magnetic blender

- Measuring flask

\section{Synthesis of Biodiesel}

The process used for preparation of biodiesel was transestrification. In this process, first the catalyst was prepared by mixing catalyst $(\mathrm{NaOH})$ with alcohol (methanol), which yielded water $\left(\mathrm{H}_{2} \mathrm{O}\right)$ and methoxide $\left(\mathrm{CH}_{3} \mathrm{O}^{-}\right)$. Afterwards, the reaction between triglysceride (vegetable oil) and methanol took place, which yielded biodiesel and glycerin. The stoiciometric and typical amounts of the reactants and products are shown in Figure 1 [Picture Credits (PennState College of Earth and Mineral Sciences, 2020)].

It is interesting to see that the amount of methanol deployed is almost double which is to ensure the completion of reaction. The overall reaction takes 2-4 hours depending upon the temperature it achieves during the reaction. The speed of reaction may be increased by further addition of alcohol. Following steps indicate our overall procedure for biodiesel synthesis:

- First, we took powdered $\mathrm{NaOH}$ about 3.5 grams and put it into the flask.

- Then measured $200 \mathrm{ml}$ of methanol in measuring flask.

- Afterwards, we added this $200 \mathrm{ml}$ methanol in the flask containing $\mathrm{NaOH}$ powder.

- Next, we put the flask on the magnetic blender and allowed it to mix until all the powder got uniformly dissolved. 


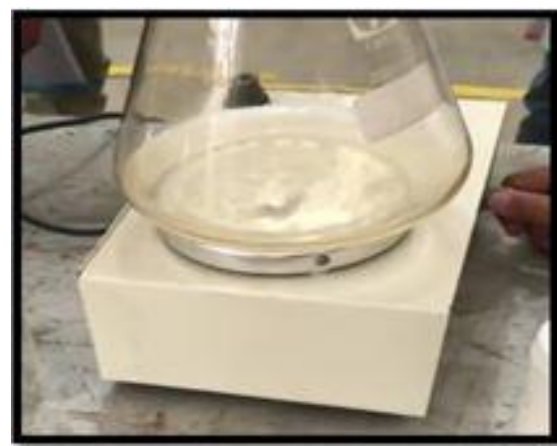

Figure 2. Stirring on the magnetic blender

Table 1. Engine Specifications

\begin{tabular}{cc}
\hline & Engine Model \\
No. of Cylinders & TD 23 \\
No. of Cycles & 4 \\
Load Cell & 4 \\
Dynamo Model & $980.7 \mathrm{~N}$ \\
Output Max & $\mathrm{EWS}-150-\mathrm{L}$ \\
Diameter of Air Nozzle & $44.13 \mathrm{~kW}$ \\
Stroke & $51 \mathrm{~mm}$ \\
Bore & $92 \mathrm{~mm}$ \\
Swept Volume & $89 \mathrm{~mm}$ \\
Torque Arm & $2289 \mathrm{ml}$ \\
Compression Ratio & $0.2865 \mathrm{~m}$ \\
\hline
\end{tabular}

Table 2. Observed Data for $14 \%$ Biodiesel

\begin{tabular}{ccccc}
\hline Sr. No. & Engine Speed (RPM) & Voltage (Volts) & Current (Ampere) & Time for 25 ml fuel consumption (sec) \\
\hline 1 & 800 & 180 & 52.5 & 70 \\
2 & 900 & 150 & 63.6 & 63 \\
3 & 1100 & 180 & 63.6 & 45 \\
4 & 1200 & 197 & 63.6 & 44 \\
\hline
\end{tabular}

Table 3. Observed Data for Pure Diesel

\begin{tabular}{ccccc}
\hline Sr. No. & Engine Speed (RPM) & Voltage (Volts) & Current (Ampere) & Time for 25 ml fuel consumption (sec) \\
\hline 1 & 800 & 168 & 57.7 & 75 \\
2 & 900 & 165 & 63.6 & 64 \\
3 & 1100 & 185 & 63.6 & 51 \\
4 & 1200 & 194 & 63.6 & 49 \\
\hline
\end{tabular}

- Next, we took 1-litre of vegetable oil and added it into the solution of $\mathrm{NaOH}$ and methanol.

- Allowed it to mix for 25 minutes on magnetic blender.

- When the layers started to form, we stopped the blender and allowed it to settle for 24 hours or so.

- The mixture automatically developed 2 layers - one of biodiesel and another of glycerin. The top layer was biodiesel as it is less dense. We separated it from glycerin.

\section{Use of 14\% Biodiesel in the $\mathrm{Cl}$ Engine with Engine Testbed}

- Now we were supposed to use this biodiesel in 14:86 with diesel to run it in a 4-stroke $\mathrm{Cl}$ engine with the engine testbed.

- The total volume of the mixture prepared was $800 \mathrm{~mL}$ in which $112 \mathrm{~mL}(14 \%)$ was bio-diesel whereas $688 \mathrm{~mL}$ was pure diesel. The mixture was prepared in a beaker that had volume readout. First, we poured bio-diesel up to $112 \mathrm{~mL}$ mark, then added diesel until the total volume of the mixture reaches $800 \mathrm{~mL}$.

- Next, we filled the engine fuel gauge with the prepared fuel mixture.

- Then we started the engine and let it settled down.

- After making sure that the engine and the testbed were working smoothly, we set a specific rpm and noted the time for $25 \mathrm{~mL}$ of fuel consumption. Moreover, we noted down the parameters such as voltage, current, torque, and load from the gauges/meters on the testbed.

- Then we reperformed the experiment with different RPMs and noted down the readings.

- After that, we repeated all of the above steps using pure diesel.

- Next, we calculated the required parameters to draw the characteristic curves. 


\section{RESULTS \& DISCUSSION}

\section{Specimen Calculations}

(For the first row of datapoints of $14 \%$ Biodiesel)

$$
\begin{gathered}
\text { Volume Flow rate }(Q)=\frac{\text { Vol }}{t}=\frac{25}{70} \times 10^{-6}=3.57 \times 10^{-7} \frac{\mathrm{m}^{3}}{\mathrm{sec}} \\
\therefore \text { Density of Pure Diesel }=832 \frac{\mathrm{kg}}{\mathrm{m}^{3}} \\
\therefore \text { Density of Pure Biodiesel }=874 \frac{\mathrm{kg}}{\mathrm{m}^{3}} \\
\text { Density of } 14 \% \text { BioDiesel }(\rho)=0.14 \times 874+0.86 \times 832=837.88 \frac{\mathrm{kg}}{\mathrm{m}^{3}} . \\
\text { Mass Flow rate }(\mathrm{mfr})=837.88 \times 3.57 \times 10^{-7}=0.000299243 \frac{\mathrm{kg}}{\mathrm{sec}} . \\
\therefore \text { C. } . \text { of Pure Diesel }=45.5 \frac{\mathrm{MJ}}{\mathrm{kg}} \\
\text { C.V.of } 14 \% \text { Biodiesel }=0.14 \times 37.7+0.86 \times 45.5=44.41 \frac{\mathrm{MJ}}{\mathrm{kg}} . \\
\text { Brake Power }(\text { B. P. })=0.45 \times 180 \times 52.5=4252.5 \mathrm{~W} .
\end{gathered}
$$

Where 0.45 is the correction factor for the engine testbed.

$$
\begin{gathered}
\text { Torque }(T)=\frac{4252.5 \times 60}{2 \times \pi \times 800}=50.76 \mathrm{Nm} . \\
\text { Brake Thermal Efficiency }(B T E)=\frac{4252.5 \times 100}{0.000299243 \times 44.41 \times 10^{6}}=32.00 \% . \\
\text { Specific Fuel Consumption }(S F C)=\frac{0.000299243 \times 1000 \times 3600}{4252.5}=\frac{0.2533 \mathrm{~kg}}{\mathrm{kWh} .}
\end{gathered}
$$

The graphs are plotted by taking engine speed (RPMs) on the horizontal axis (X-axis); brake power, torque, brake thermal efficiency and specific fuel consumption are taken on the vertical axis ( $\mathrm{Y}$-axis) separately. In our case, we wanted to make a comparison between pure diesel and $14 \%$ biodiesel ( $14 \%$ of biodiesel $+86 \%$ of diesel). For that purpose, we plotted the characteristics curves of diesel and biodiesel blend on a single graph.

\section{Engine Speed vs Brake Power}

Figure 3 shows the variation in brake power with respect to the engine speed. As seen from the graph, brake power continues to increase with the increase in the engine speed for both pure diesel and $14 \%$ biodiesel ( $14 \%$ of biodiesel $+86 \%$ of diesel). This is due to the fact that when engine speed increases (at higher RPMs), more fuel is brought into the cylinder during each cycle. As a result, more combustion of fuel takes place which, in turn, produces more power. Therefore, we can interpret that the brake power will increase with the increase in engine speed. Initially, the brake power increases more or less linearly; however, after a certain engine speed is reached, brake power varies non-linearly until it reaches the maximum at a certain designed speed. Further increase in the engine speed will result in a decrease in B.P. due to the decrease in volumetric efficiency. From our graph, we can see that both of our curves have positive slope throughout which implies that we may have not yet reached the optimum designed speed for this given engine.

The graph shows that for the most part, the brake power of diesel fuel is greater than that of the biodiesel blend ( $14 \%$ of biodiesel $+86 \%$ of diesel), which was already expected. This is due to the reason that the calorific value of diesel is $45.5 \mathrm{KJ} / \mathrm{kg}$ and that of the mixture is around $44 \mathrm{KJ} / \mathrm{kg}$. The calorific values of both of them show that the diesel will liberate more energy $(45.5 \mathrm{KJ} / \mathrm{kg})$ as compared to that coming from the mixture of biodiesel blend $(44 \mathrm{KJ} / \mathrm{kg})$, by the combustion of $1 \mathrm{~kg}$ of each fuel. Hence, pure diesel will generate more brake power.

Towards the end of the curve, we see strange behaviour. At around $1200 \mathrm{rpms}, 14 \%$ biodiesel is yielding more brake power as compared to pure diesel. This can be attributed to the higher viscosity of biodiesel blend, which provides greater lubricity, 


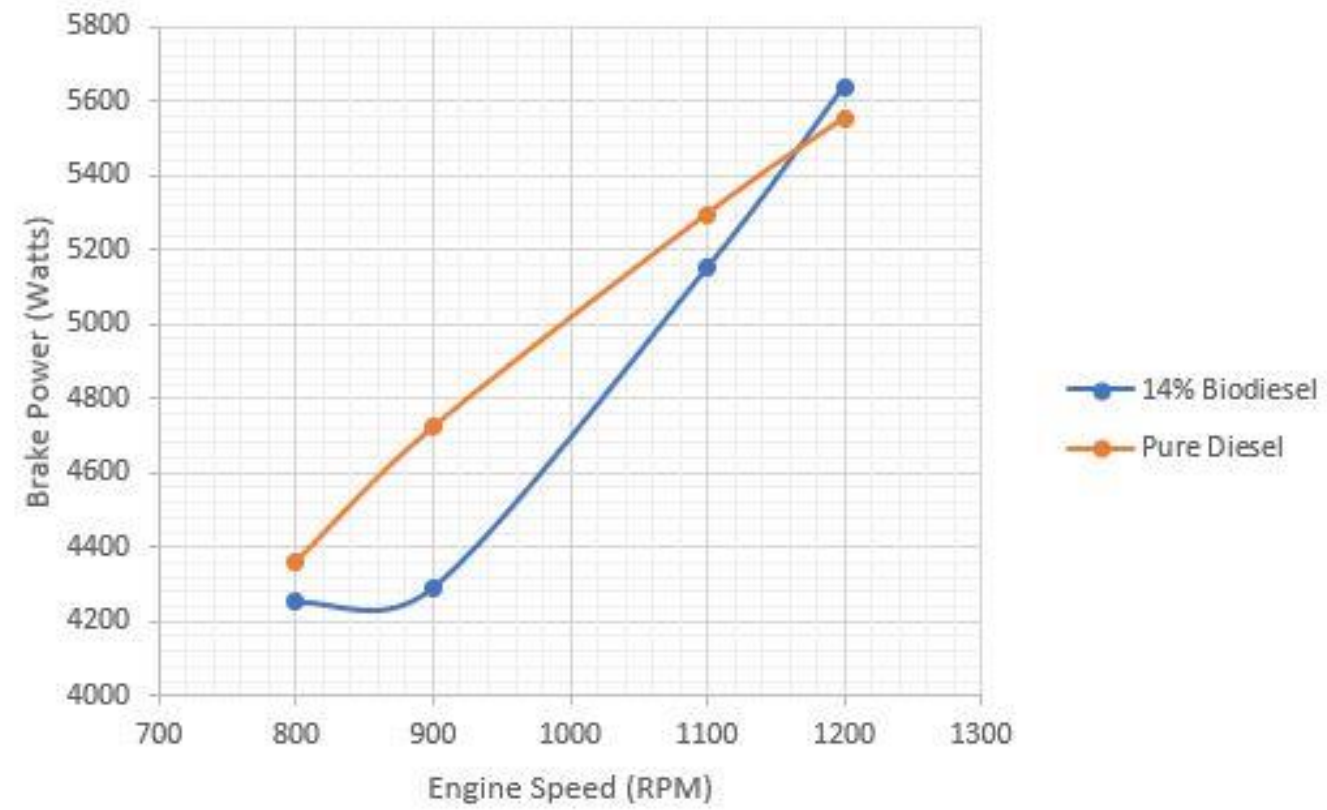

Figure 3. Plot between engine speed and brake power

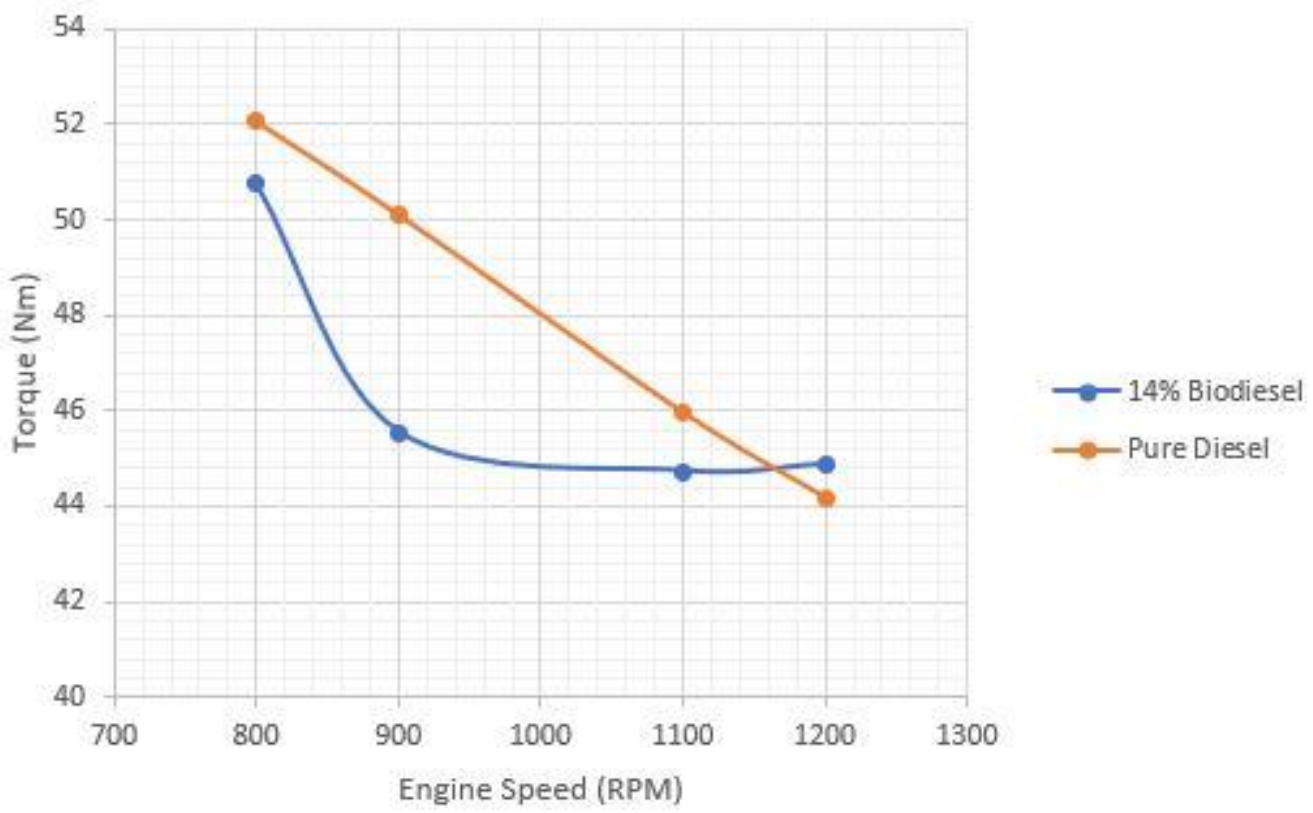

Figure 4. Plot between Engine Speed and Torque

appropriate spray \& better atomization, and thus better combustion as compared to the pure diesel at higher speeds (Harne et al., 2017). Therefore, we may interpret that our engine will work best with $14 \%$ biodiesel at higher engine speeds.

\section{Engine Speed vs Torque}

Figure 4 shows the variation of torque with the increase in engine speed. In case of pure diesel, torque is decreasing linearly with the increase in engine speed. Actually, the graphs have been plotted by first making the engine run at maximum speed ( 1200 rpm) while keeping the throttle at fully opened position. After that, a certain amount of load is applied resulting in a decrease in engine speed. As load is increased further, engine speed will continue to decrease resulting in an increase of torque. This can easily be understood by reading the graph from right to left. Therefore, torque increases with the decrease in engine speed.

$$
\text { B.P. }=2 \pi N T \rightarrow \text { Torque } \propto \frac{1}{\text { Speed }}
$$

This resulting increase in torque due to increase in load and reduction in speed can also be attributed to better combustion at higher loads and lower speeds (Stalin and Prabhu, 2007). This is in line with the literature already available to us. For the most part, the torque due to pure diesel is greater than that due to $14 \%$ biodiesel, as shown in the figure. This is due to the lower calorific 


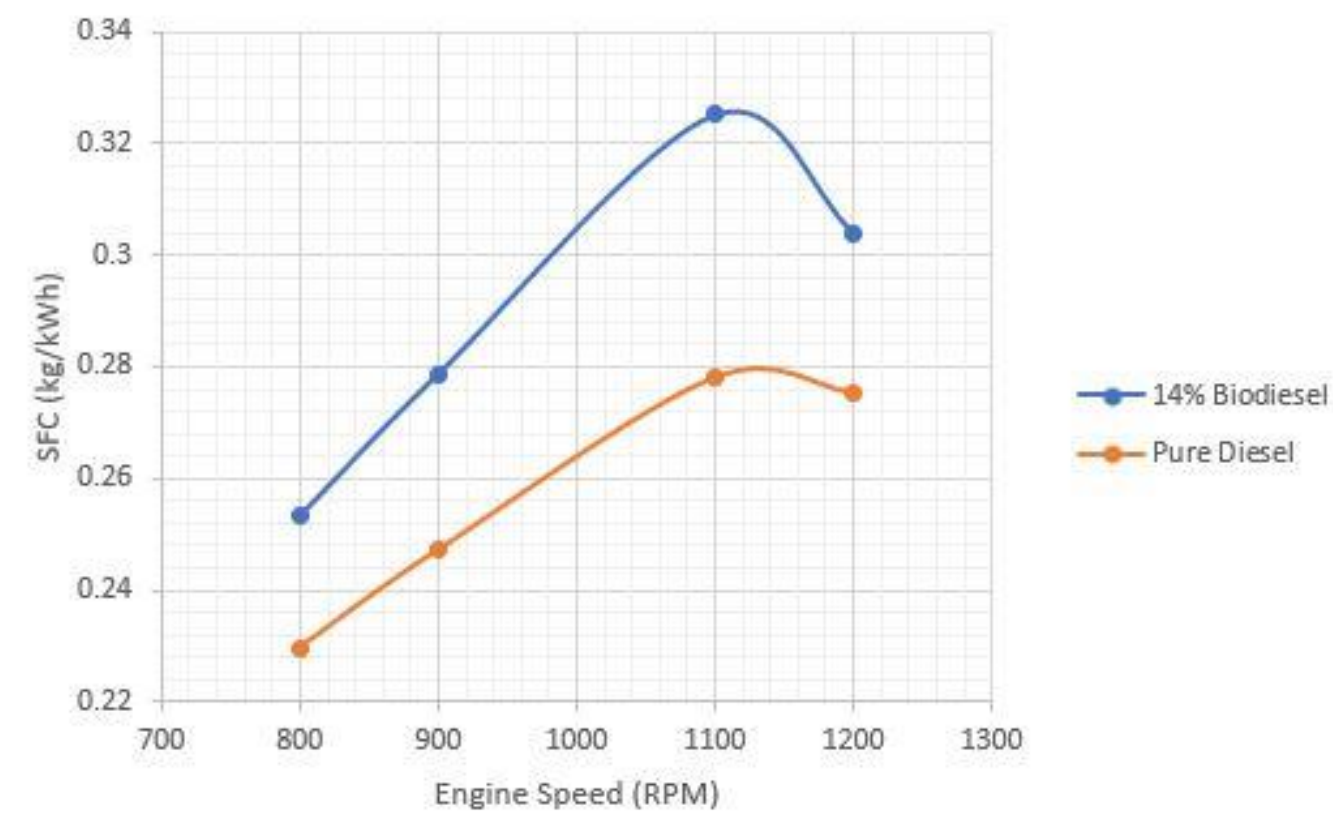

Figure 5. Plot between Engine speed and specific fuel consumption

value of the biodiesel blend than that of diesel. Due to this, the mixture of biodiesel and diesel will liberate less heat as compared to diesel for the combustion of the same amount of both fuels.

It is usually desirable for engines to have a greater amount of torque at both lower and higher speeds since a greater amount of torque will mean greater brake power (Equation 9). At lower engine speeds, this is rather easy to achieve. Hence, the torque will increase with increase in engine speed, reaching the optimum value at a particular designed speed and beyond that, it will decrease. In our case, the $\mathrm{Cl}$ engine behaves unusually. In fact, torque from biodiesel blend is greater than that from pure-diesel at $1200 \mathrm{rpm}$, which is due to the less appropriate atomization and combustion of pure diesel as compared to biodiesel blend at that engine speed. Since greater torque means greater brake power, it is preferrable to run the engine at higher speeds when using the biodiesel blend since that will lead to the more effective use of heat energy of biodiesel blend (Harne et al., 2017).

\section{Engine Speed vs Specific Fuel Consumption}

Figure 5 shows the variation of specific fuel consumption (S.F.C) with engine speed. Specific fuel consumption indicates the engine's combustions efficiency and is defined as the amount of fuel consumed per unit brake power. As seen from the graph, the trend for both pure diesel and $14 \%$ biodiesel is similar. Specific fuel consumption is increasing as the engine speed increases. This is due to the fact that at higher engine speeds, more fuel is consumed which accounts for more brake power and greater frictional losses. Normally, specific fuel consumption decreases initially until the optimum speed is reached and then starts increasing. At optimum speed, the SFC is minimum and engine is most economical. The graph shows that the specific fuel consumption of diesel is less than that of a mixture of biodiesel and diesel. This is due to the reason that the calorific value of diesel is greater than that of the biodiesel blend. It means that diesel will liberate more energy as compared to $14 \%$ biodiesel. For the mixture of biodiesel to give the same amount of energy as that of diesel at the same engine speed, more quantity of $14 \%$ biodiesel is required. As a result, S.F.C of $14 \%$ biodiesel is greater than that of diesel.

At $1200 \mathrm{rpm}$ engine speed, both diesel and $14 \%$ biodiesel combust more efficiently as compared to $1100 \mathrm{rpm}$. The S.F.C. is highest at 1100 RPMs, hence the engine should not be run at this speed for economic reasons. If this engine is to be run at over $1000 \mathrm{rpm}$, it should be run at 1200 RPMs when using $14 \%$ biodiesel because not only it would be more economical, it would also yield greater torque and highest brake power at this speed.

\section{Engine Speed vs Brake Thermal Efficiency}

Figure 6 shows the variation in brake thermal efficiencies of pure-diesel \& 14\% biodiesel with an increase in engine speed. The brake thermal efficiency would be maximum at particular designed engine speed. From the mathematical equation (equation 7), BTE depends upon B.P. and fuel consumption. In the experiment, brake thermal efficiency is greater at the start and then it decreases with the increase in engine speed. This is due to the reason that fuel consumption is more at higher engine speed although the engine is developing more power. Brake thermal efficiency of the mixture of $14 \%$ biodiesel is less than that of pure diesel, as anticipated. This is due to the lower calorific value of mixture biodiesel and diesel than that of diesel.

The trend for the Engine speed versus the brake thermal efficiency is opposite of that of engine speed versus S.F.C. In order to achieve maximum BTE and lowest S.F.C., the engine should be run at 800rpm for either type of fuel. The BTE is lowest at $1100 \mathrm{rpm}$; beyond that i.e. 1200 RPMs, both diesel and $14 \%$ biodiesel combust more efficiently. Therefore, we should avoid running the engine at 1100 RPMs. 


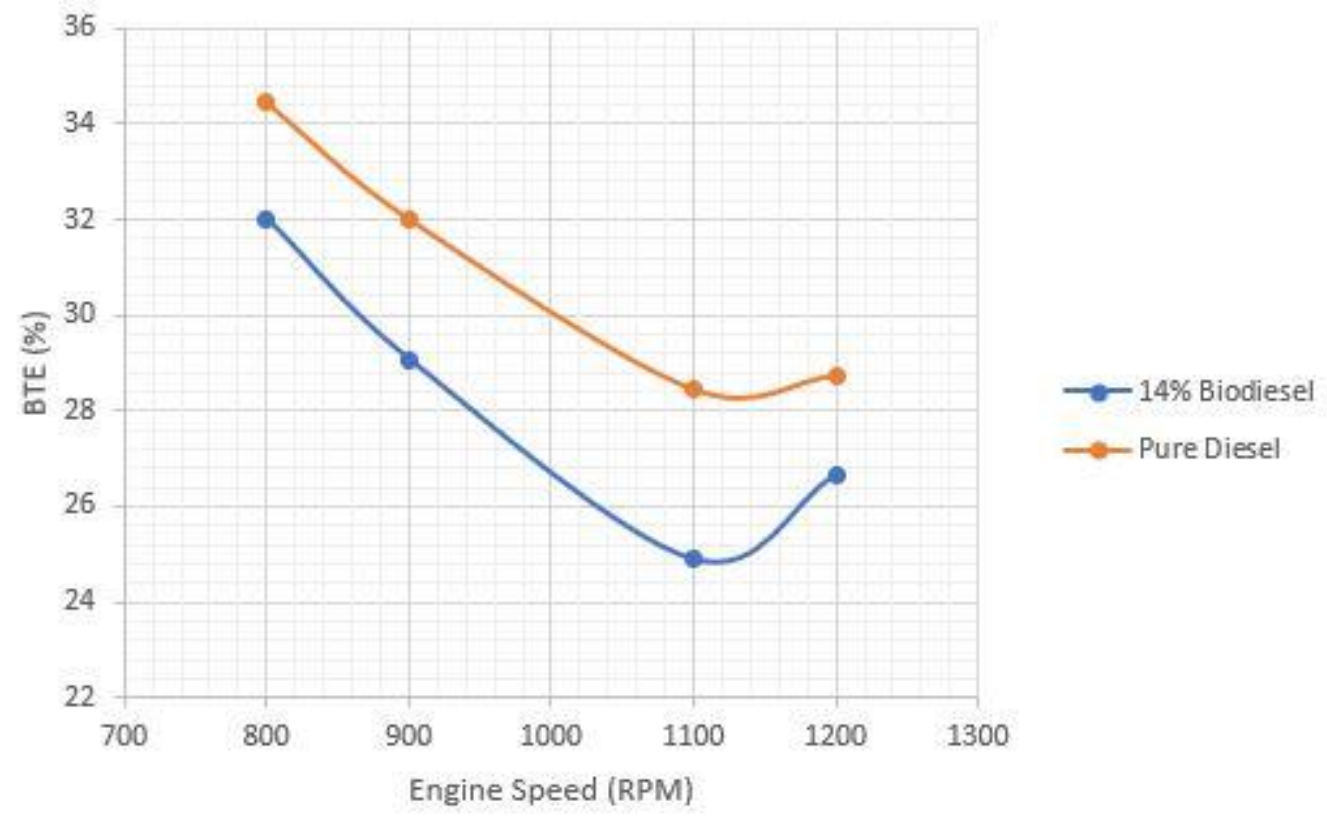

Figure 6. Plot between Engine Speed and Brake thermal efficiency

\section{CONCLUSIONS}

One of the major drawbacks of using biodiesel is that it is more expensive than conventional fuels (Diesel, Petrol etc.). Furthermore, the calorific value of bio-diesel is lower than that of petrol or diesel, which means that it would give us lower brake power. These are the main reasons why this technology can't be considered a replacement for fossil fuels for now. The only benefit of the bio-diesel is that it is less hazardous as compared to conventional fuels. Thus, it is less of a threat to the environment and more sustainable. It's estimated that use of $20 \%$ biodiesel ( $20 \%$ biodiesel $+80 \%$ diesel) may reduce unburned hydrocarbon emissions by $30 \%$, carbon monoxide and sulphates emissions by $20 \%$ and particulate matter emission by $22 \%$ as compared to emissions from pure diesel. However, it does, in fact, increase the nitrogen oxide emissions by a slight fraction (+2\%). The use of alcohol and renewable oil/fats is the reason why biodiesel reduces hazardous carbon emissions to the atmosphere. In order to promote the use of biodiesel, the manufacturers need to develop specially made biodiesel combustion engine. The commercial use of these engines could revolutionize the transportation sector, a major consumer of fossil fuels. By deploying these engines on automobiles, we could greatly curb the environmental hazards due to conventional fossil-fuel.

\section{ACKNOWLEDGEMENTS}

The authors are thankful to the lab in-charge, Mr Muhammad Usman, who supervised our work throughout our time in the IC Engines Lab. We are also thankful to Mr Faisal who guided and helped us with our experimental work.

\section{REFERENCES}

Abed, K. A., Gad, M. S., El Morsi, A. K., Sayed, M. M. and Elyazeed, S. A. (2019). Effect of biodiesel fuels on diesel engine emissions. Egyptian Journal of Petroleum, 28(2), 183-188. https://doi.org/10.1016/j.ejpe.2019.03.001

Dufey, A. (2006) Biofuels production, trade and sustainable development: emerging Issues. International Institute for Environment and Development (pp. 7-11). London, UK: IIED

Fan, X. and Burton, R. (2009). Recent Development of Biodiesel Feedstocks and the Applications of Glycerol: A Review. Open Fuels \& Energy Science Journal, 2, 100-109. https://doi.org/10.2174/1876973X00902010100

Ge, J. C., Kim, M. S., Yoon, S. K. and Choi, N. J. (2015). Effects of Pilot Injection Timing and EGR on Combustion, Performance and Exhaust Emissions in a Common Rail Diesel Engine Fueled with a Canola Oil Biodiesel-Diesel Blend. Energies, 8(7), $7312-7325$. https://doi.org/10.3390/en8077312

Gerpen, V. J. (2005) Biodiesel Processing and Production. Fuel Processing Technology, 86(10), 1097-1107. https://doi.org/10.1016/j.fuproc.2004.11.005

Harne, M. S., Pelagade, M. A. and Shrivastava, R. (2017). Performance Evaluation of Cl Engine using Karanja Biodiesel as an Alternative Fuel. International Journal of Scientific Research in Science and Technology, 3(6), 302-308. 
Jaichandar, S. and Annamalai, K. (2011). The Status of Biodiesel as an Alternative Fuel for Diesel Engine-an Overview. Journal of Sustainable Energy \& Environment, 2(2), 71-75.

Kim, H. Y., Ge, J. C. and Choi, N. J. (2018). Application of Palm Oil Biodiesel Blends under Idle Operating Conditions in a CommonRail Direct-Injection Diesel Engine. Applied Sciences, 8(12), 2665. https://doi.org/10.3390/app8122665

Knothe, G. (2005). Dependence of Biodiesel Fuel Properties on the Structure of Fatty Acid Alkyl Esters. Fuel Processing Technology, 86(10), 1059-70. https://doi.org/10.1016/j.fuproc.2004.11.002

Liu, P., Shu, G., Tian, H. and Wang, X. (2018). Engine Load Effects on the Energy and Exergy Performance of a Medium Cycle/Organic Rankine Cycle for Exhaust Waste Heat Recovery. Entropy, 20(2), 137. https://doi.org/10.3390/e20020137

Ma, F. and Hanna, M. A. (1999). Biodiesel Production: A Review. Bioresource Technology, 70(1), 1-15. https://doi.org/10.1016/S09608524(99)00025-5

Meher, L. C., Sagar, D. V. and Naik, S. N. (2006) Technical Aspects of Biodiesel Production by Transesterification-a Review. Renewable and Sustainable Energy Reviews, 10(3), 248-68. https://doi.org/10.1016/j.rser.2004.09.002

Niculescu, R., Clenci, A. and Iorga-Siman V. (2019). Review on the Use of Diesel-Biodiesel-Alcohol Blends in Compression Ignition Engines. Energies, 12(7), 1194. https://doi.org/10.3390/en12071194

PennState College of Earth and Mineral Sciences. (2020). The reaction of Biodiesel: Transesterification. Online.

Sheehan, J., Dunahay, T., Benemann, J. and Roessler, P. (1998). A Look Back at the US Department of Energy's Aquatic Species Program: Biodiesel from Algae; Close-Out Report. United States. https://doi.org/10.2172/15003040

Singh, B., Guldhe, A., Rawat, I. and Bux, F. (2014). Towards a Sustainable Approach for Development of Biodiesel from Plant and Microalgae. Renewable and Sustainable Energy Reviews, 29, 216-45. https://doi.org/10.1016/j.rser.2013.08.067

Songstad, D., Lakshmanan, P., Chen, J., Gibbons, W., Hughes, S, and Nelson, R. (2011). Historical Perspective of Biofuels: Learning from the Past to Rediscover the Future. Biofuels (pp. 1-7). New York, NY: Springer. https://doi.org/10.1007/978-1-4419-7145$6 \_1$

Stalin, N. and Prabhu, H. J. (2007). Performance Test of IC Engine Using Karanja Biodiesel Blending with Diesel. ARPN Journal of Engineering and Applied Sciences, 2(5), 32-34.

Teoh, Y. H., Yu, K. H., How, H. G. and Nguyen, H.-T. (2019). Experimental Investigation of Performance, Emission and Combustion Characteristics of a Common-Rail Diesel Engine Fuelled with Bioethanol as a Fuel Additive in Coconut Oil Biodiesel Blends. Energies, 12(10), 1954. https://doi.org/10.3390/en12101954

Yoon, S. K., Ge, J. C. and Choi, N. J. (2019). Influence of Fuel Injection Pressure on the Emissions Characteristics and Engine Performance in a CRDI Diesel Engine Fueled with Palm Biodiesel Blends. Energies, 12(20), 3837. https://doi.org/10.3390/en12203837

\section{APPENDIX A}

Table A1. Observed \& Calculated Data for 14\% Biodiesel

\begin{tabular}{|c|c|c|c|c|c|c|c|c|c|c|}
\hline Sr. No & $\begin{array}{c}\text { Engine Speed } \\
\text { (RPM) }\end{array}$ & $\begin{array}{c}\text { Voltage } \\
\text { (Volts) }\end{array}$ & $\begin{array}{c}\text { Current } \\
\text { (Ampere) }\end{array}$ & time (sec) & $\begin{array}{c}Q \\
\left(10^{-7}, \mathrm{~m}^{3} / \mathrm{s}\right)\end{array}$ & $\begin{array}{c}\mathrm{mfr} \\
\left(10^{-4}, \mathrm{~kg} / \mathrm{sec}\right)\end{array}$ & $\begin{array}{l}\text { B.P. } \\
\text { (W) }\end{array}$ & $\begin{array}{c}\text { Torque } \\
(\mathrm{Nm})\end{array}$ & $\begin{array}{l}\text { BTE } \\
(\%) \\
\end{array}$ & $\begin{array}{c}\text { SFC } \\
(\mathrm{kg} / \mathrm{kWh})\end{array}$ \\
\hline 1 & 800 & 180 & 52.5 & 70 & 3.57 & 2.99 & 4252.5 & 50.76 & 32.00 & 0.2533 \\
\hline 2 & 900 & 150 & 63.6 & 63 & 3.97 & 3.32 & 4293.0 & 45.55 & 29.08 & 0.2788 \\
\hline 3 & 1100 & 180 & 63.6 & 45 & 5.56 & 4.65 & 5151.6 & 44.73 & 24.92 & 0.3253 \\
\hline 4 & 1200 & 197 & 63.6 & 44 & 5.68 & 4.76 & 5638.1 & 44.87 & 26.67 & 0.3040 \\
\hline
\end{tabular}

Table A2. Observed \& Calculated Data for Pure Diesel

\begin{tabular}{|c|c|c|c|c|c|c|c|c|c|c|}
\hline Sr. No. & $\begin{array}{c}\text { Engine Speed } \\
\text { (RPM) }\end{array}$ & $\begin{array}{c}\text { Voltage } \\
\text { (Volts) }\end{array}$ & $\begin{array}{c}\text { Current } \\
\text { (Ampere) }\end{array}$ & time (sec) & $\begin{array}{c}Q \\
\left(10^{-7}, \mathrm{~m}^{3} / \mathrm{s}\right)\end{array}$ & $\begin{array}{c}\mathrm{mfr} \\
\left(10^{-4}, \mathrm{~kg} / \mathrm{sec}\right)\end{array}$ & $\begin{array}{l}\text { B.P. } \\
\text { (W) }\end{array}$ & $\begin{array}{c}\text { Torque } \\
\text { (Nm) }\end{array}$ & $\begin{array}{l}\text { BTE } \\
(\%) \\
\end{array}$ & $\begin{array}{c}\text { SFC } \\
(\mathrm{kg} / \mathrm{kWh})\end{array}$ \\
\hline 1 & 800 & 168 & 57.7 & 75 & 3.34 & 2.78 & 4362.1 & 52.07 & 34.45 & 0.2296 \\
\hline 2 & 900 & 165 & 63.6 & 64 & 3.90 & 3.24 & 4722.3 & 50.11 & 32.02 & 0.2471 \\
\hline 3 & 1100 & 185 & 63.6 & 51 & 4.91 & 4.09 & 5294.7 & 45.97 & 28.46 & 0.2780 \\
\hline 4 & 1200 & 194 & 63.6 & 49 & 5.10 & 4.25 & 5552.3 & 44.18 & 28.75 & 0.2752 \\
\hline
\end{tabular}

